\title{
Austro-German Liberalism and the Coming of the 1867 Compromise: 'Politics Again in Flux'
}

On 7 October 1866, Adolf Pratobevera - a prominent liberal politician and former Justice Minister - wrote in his diary that 'politics [is] again in flux, whether this is a blessing? God knows'. ${ }^{1}$ Pratobevera was writing just three months after the battle of Königgrätz/Hradec Králové in a period of immense instability and uncertainty for the Habsburg Monarchy. ${ }^{2}$ The traditional supports of the system - the Emperor, the army and the bureaucracy - were in a weakened state following Austria's military defeat at Königgrätz and this dramatically opened the range of possibilities in politics. Indeed, the defeat threw the whole political system in question; a situation which sharply exposed the fault lines and internal political workings of the Monarchy. In the period from Königgrätz on 3 July 1866 to the ministerial meeting on 1 February 1867 (when the Emperor definitively decided on the dualist structure), all political parties and movements had the opportunity to define their programmes, to seek possible allies and argue their particular vision of the Monarchy's political structure.

This article focuses on those crucial seven months and on the role of the AustroGerman liberals in setting the terms of the new dualist system. Traditional interpretations viewed the liberals as dogmatic, divided and impotent during this period since they were split between competing factions, did not have a minister close to the Crown, did not participate in the Compromise negotiations and were never formally summoned to consult with the Emperor. ${ }^{3}$ Indeed, apart from the recent work of Éva Somogyi and Pieter Judson, the role of the Austro-German liberals in the genesis of the 1867 Compromise has been largely ignored. ${ }^{4}$ This article traces two themes: first, the exertion of public pressure by the 
liberals and, second, the convergence of the various liberal factions around a consensus position. To a large extent, the former provided the background accompaniment to the latter. By asserting their influence where possible and by eventually presenting a united front, the liberals played a key role in the 1867 political settlement. Their repeated demands for a liberal constitutional system meant that when Emperor Francis Joseph required their support to realise the 1867 Compromise with Hungary, the liberals could insist on drafting and installing a progressive, liberal constitution along with an extensive institutional and legal framework.

Throughout the seven months of political flux, the liberals had to balance a powerful assertion of liberal demands against the danger of alienating the Emperor and his government. It was a difficult balance. Austro-German liberal influence at this time was based on public discourse, informal contacts, organizational networks and institutional leverage. By utilising these channels the Austro-German liberals constituted an important factor in the mental framework and the practical limits for any new settlement. For example, even as Prussian troops were approaching Vienna, municipal representative bodies with liberal majorities bravely - perhaps foolishly - sent messages directly to the Emperor questioning his government's conduct. In addition, the liberal press - both in newspapers and contemporary brochures - vigorously debated government decisions, constitutional matters, political tactics, the nature of parliament and the place of German-speakers in the Monarchy. Not only did this public discussion promote a clear articulation of liberal demands, it also continued the process of developing the public sphere and opening governmental decision making.

Coupled with this overt, wide-ranging pressure on the Emperor and his ministers, the vast majority of liberals - when under threat and facing an uncertain future - showed a 
combination of ideological flexibility and hard-headed pragmatism to unite around realisable shared core beliefs. This process was neither straight-forward nor smooth. In terms of traditions, organization, political structure and ideology, the Austro-German liberal movement tended towards division and difference. Between such disparate regions as Tyrol, Bohemia, Styria, Vienna and so on, conditions, issues and personalities varied enormously. This article plots the machinations of the liberal factions in detail in an attempt to portray both the wide spectrum of liberal opinion and the gradual, difficult process of achieving unity in action and principles. By January 1867 all of the major factions within the liberal movement were prepared to accept and implement the Compromise with Hungary provided that the Emperor and his government respected two fundamental conditions: the reinstallation of constitutional life and the building of a centralist, liberal Cisleithanian state. ${ }^{5}$ Both conditions contained the unspoken, implicit assumption of political and cultural hegemony for German-speakers in the Cisleithanian political and administrative structure. ${ }^{6}$ The exertions of the liberals finally came to fruition in December 1867 with the promulgation of constitutional laws and the installation of the so called Burger Ministry (Bürgerministerium) consisting of liberal parliamentarians. This represented the high water mark of Austro-German liberalism. These achievements in 1867 all rested on a sustained campaign of liberal public pressure and on the coalescence of Austro-German liberal factions.

At the outbreak of the Austro-Prussian war, the liberals had been preoccupied with fighting the new government of Count Richard Belcredi, which had been in place since 27 July 1865. 
In particular, Belcredi's 1865 September Manifesto which suspended the 1861 February Patent (and thus also the Imperial Parliament) had provoked sustained and vocal protest from the liberals. Belcredi had wanted to facilitate negotiations with Hungarian representatives who had boycotted the Imperial Parliament - and to induce their participation in state and political institutions. The Austro-German liberals, on the other hand, defended the February Patent which, with some reservations, they treated as a starting point for the development of a truly liberal and progressive Austria. ${ }^{7}$ Throughout the early to mid 1860 s - sometimes in harmony but later increasingly in conflict with Anton Schmerling's bureaucratic, liberalleaning government - the parliamentary liberals had worked on legislation (with varying degrees of success) for communal autonomy, ministerial responsibility, immunity for representatives, financial and economic laws, an independent judiciary, freedom of the press and a secular State. These issues were fundamental to nearly all liberals and relatively uncontentious within their ranks. The liberals were loyal to the February Patent (they called it the February Constitution) as the starting point for liberal reforms and had formed a loose political grouping under the umbrella term, the Constitutional Party (Verfassungspartei).

Despite the existence of the Constitutional Party, there was little party discipline in the early to mid 1860s. It was a time of fluid ideologies and provisional judgements as the liberals sought to articulate their vision of Austria. In terms of state structure, most liberal viewpoints were perched somewhere between strict governmental centralism and extensive local autonomy, often including arguments from both ends of the spectrum. ${ }^{8}$ Of the many liberal factions, the strict centralists were mainly from Vienna and Moravia and remained ideologically opposed to any special privileges for Hungary. Their principal goal was to install centralist institutions based in Vienna, to set up a legal framework consistent throughout the whole Monarchy and to infuse government with a liberal spirit. Close to the 
centralists were the Bohemian Germans. Conscious of their potential minority status in the Bohemian Diet (this depended on the composition of the Bohemian Great Landowners' curia) they formed a unified bloc. Most Bohemian German politicians looked to a strong central Viennese government and parliament as the best policy for ensuring liberal progress and protecting Bohemian German interests. ${ }^{9}$ Their parliamentary leader was the upright, strict, legal professor Eduard Herbst, sarcastically known as 'King Eduard of GermanBohemia'. ${ }^{10}$ His political convictions remained essentially the same throughout his long public life: a central state (which automatically protected the German position in Bohemia and Austria), a strong parliament and a constitutional, modern Austria. He fought against any hints of federalism and absolutism. While often criticised by his colleagues as negative and 'the misfortune of the party', beneath Herbst's formidable political exterior lay a conception of a centralised Austria with a watchful, independent, powerful parliament. ${ }^{11}$

At the other end of the liberal spectrum, the more radical liberals emphasised the protection of individual rights, ministerial responsibility and parliamentary control over state expenditure - all directly or indirectly restricting the power and authority of the state. Many of these liberals were in the Autonomist camp, based in Styria and Upper Austria. The Autonomists placed their faith in communal autonomy as the centre of political life; it should, they argued, form the fundament of the state structure. ${ }^{12}$ One of their leaders Moriz von Kaiserfeld criticised liberalism's centralist tendencies in a letter dated 4 March 1866:

I am very worried about the centralist ideas which are so deep in their [the centralists'] souls. Instead of restricting their ideas to the lands on this side of the Leitha (i.e. the German provinces), the centralists extend them to the whole Monarchy, where they don't have sufficient strength for such leadership. Whoever 
doesn't have political rule will be oppressed. Whoever cannot be the hammer in this tangle of nationalities must become the anvil. ${ }^{13}$

After the installation of the Belcredi government, the Autonomists had sought contact with their Hungarian liberal counterparts and were open to some form of mutual understanding. In February 1866 Kaiserfeld wrote to the Hungarian liberal leader Ferenc Deák that they should meet in Budapest to discuss the basis of constitutional life. Other liberals close to the Autonomist camp were prepared to put their heads above the parapet and risk censure from the strict centralists by advocating a dualist solution. Amidst feverish activity in the Hungarian parliament before the outbreak of war, Adolph Fischhof, a hero of the 1848 Revolutions, published an article in the Pester Lloyd (Budapest's main German newspaper) in January 1866 identifying himself as joint author of the 1861 dualist brochure Zur Lösung der ungarischen Frage. He showed evident sympathy with Hungary’s cause; 'born in Hungary, I have always remained affectionate towards it with love, warmth and loyalty'. ${ }^{14}$

On the Hungarian side, the moderate liberals grouped around Ferenc Deák presented a united front and were well placed leading up to the outbreak of war. Their leverage stemmed from an insistence on the 1848 April Laws, a refusal to accept the February Constitution, their boycott of its institutions and the subsequent breakdown of the governmental system. The overwhelming majority of the Austro-German liberals, especially the centralists, had rejected Deák's assertion of special Hungarian rights and had supported Schmerling's attempt to form a central parliament. However, with the installation of Belcredi and the suspension of the constitution, the government seemed to favour some compromise with the Hungarians. Informal contact between Deák and an emissary of Francis Joseph's had been made in secret as early as December 1864. Within months Deák’s celebrated Easter Article appeared and on 15 December 1865 the recalled Hungarian 
parliament voted for a committee to draft the conditions of a possible Compromise. Despite some disagreements between Deák’s moderates and Kálmán Tisza’s radicals, the draft was swiftly finished and was ready for discussion as the war with Prussia broke out. ${ }^{15}$ Thus, leading up to Königgrätz, the Hungarian liberals were in powerful position. They were in dialogue with the Belcredi government, knew that the Emperor wanted a compromise and now possessed a detailed plan of their demands. The Austro-German liberals, however, were divided over possible concessions with the Hungarian politicians. Some were prepared to cede considerable autonomy while others continued to insist on centralist institutions.

In Bohemia and Moravia, the divided liberals faced the alliance of Czech nationalist politicians and conservative nobles. Politically, the Czech-conservative alliance, which was formed for tactical purposes in 1861, viewed Belcredi's suspension of the February Patent as a moment to refound the Austrian state along federalist principles. In particular, the Czechconservative alliance rested on the assertion of Bohemian state rights (including Moravian and Silesian rights). ${ }^{16}$ In the run-up to the Austro-Prussian war, after a period of German nationalist dominance since 1861, both the Bohemian and Moravian Diets were tending towards Czech-conservative majorities courtesy of governmental pressure on the 'nebulous' swing representatives in the respective Great Landowners' curias. ${ }^{17}$ Throughout 1865 , Belcredi's government had also been negotiating with the Czech nationalist and conservative noble leaders who reiterated their demand for Bohemian state rights. ${ }^{18}$ Belcredi - from a Moravian family, of strong Catholic beliefs and a fluent speaker of Czech - knew Bohemia well, while his brother Egbert Belcredi was the leader of the Moravian noble conservatives. Thus the Czech-conservative noble alliance seemed to be paying off. Francis Joseph had promised to be crowned Bohemian King and the Belcredi government was seriously considering the possibility of Bohemian state rights. ${ }^{19}$ 
The domestic situation in early 1866 was therefore still undecided and the Belcredi government had kept its options open. While all three possibilities - centralism, dualism or federalism - were on the table, circumstances and government opinion were tending to the latter two, to the detriment of Austro-German liberal centralist hopes. The Austro-German liberals found themselves without a central parliament, fighting a conservative government, excluded from consultation over the future organisation of the Monarchy, and facing minority status in the Bohemian and Moravian Diets. This meant a redoubling of efforts on the levers which remained in Austro-German liberal hands - their dominance of the press, their voice in representative institutions with liberal majorities (both municipalities and Diets) and the influence of highly placed bureaucrats with liberal centralist leanings. Through their use of the public sphere, the liberals could exert considerable pressure in the fluid, post-Königgrätz situation, despite their continued exclusion from official government negotiations.

In its first considered response to Königgrätz, the main liberal newspaper the Neue Freie Presse (NFP) set the tone for the Austro-German liberal reaction. The newspaper attributed the defeat primarily to Belcredi's conservative government and to the uncertain, unconstitutional domestic conditions for which it held him responsible. The NFP, typically, was not shy about giving advice - even at this delicate moment when the army had suffered a devastating defeat and Vienna faced occupation.

Lofty silence towards Hungary, becoming even loftier, was no way to bring about the revival which was needed for the immense undertaking of a dual war in North and 
South ... the entire domestic situation of the Empire was inappropriate to face this massive test and part of the responsibility for the present situation rests on those whose advice had helped bring it about...[Therefore] the domestic system must be totally changed, Hungary must be satisfied and the Empire on this side of the Leitha must be guaranteed a solid constitutional future through the calling of truly liberal men to advise the crown and through the reactivation of the constitution. Here lies the salvation, the possibility of rehabilitating Austria domestically and within Germany - any other way leads to new weakness and certain ruin. ${ }^{20}$

The pressure from liberal newspapers was backed up by public calls from representative bodies. Just three days after Königgrätz on 7 July 1866, the Salzburg Town Council sent a unanimous address to the Emperor calling for the restoration of the February constitution and the convening of the Imperial Parliament. ${ }^{21}$ The Graz town council followed a few days later, sending an address drafted by the prominent Autonomist liberal Karl Rechbauer. Echoing the opinions of the NFP, it called for a 'decisive break' with the past and a 'true, liberal, popular constitutional life'. The address pleaded for the Emperor to have faith in a 'free people', thus ensuring Austria's future. ${ }^{22}$

The war was not yet over. In the capital, as the population and government prepared for a Prussian advance and possible occupation, the liberal-majority Town Council was concerned about a possible battle in Vienna itself. In an audience with the Emperor, representatives of the Town Council were assured that Vienna would be an 'open city'. ${ }^{23} \mathrm{On}$ 17 July 1866, as the war came ever closer, the Vienna Town Council discussed an address to the Emperor to profess its loyalty and to express its wishes for the future. Amidst cheers from the galleries, Councillor Khunn read the address which had been drafted by a committee of prominent liberal politicians including Cajetan Felder, Joseph Kopp, Ignaz 
Kuranda, Johann N. Berger and Eduard Suess. The address blamed the calamitous situation on the unfortunate policies of the Emperor's advisors (implying his ministers). It also called for the participation of representative bodies in policy making and a 'truly liberal policy'. ${ }^{24}$ A delegation led by Mayor Andreas Zelinka delivered the address personally on 23 July 1866. The emperor immediately queried the council's jurisdiction, acknowledging the address's contents not as a representative of Vienna's will but merely as an expression of the council's individual members. The Emperor expressed his warmest wishes for return to constitutional life, but cautioned that the interests of the entire state (Gesamtstaat) had to be taken into account. ${ }^{25}$ When Mayor Zelinka delivered his account of the meeting to a council meeting the next day, there was public disquiet at the Emperor's responses, which were interpreted as questioning the residents' patriotism and willingness to sacrifice. A new delegation was sent to confirm the council's (and the population's) loyalty and to convey the public's distress at the Emperor's attitude. ${ }^{26}$ The NFP was typically forthright, stating that the whole Town Council was prepared to resign for its liberal principles were it not for the critical situation. For the NFP the council's address reflected public sentiment for the constitution and against absolutism. ${ }^{27}$ By contrast, another liberal newspaper, the Presse, supported the Emperor's position arguing that it was for him to decide upon any change to the system. ${ }^{28}$ It is instructive that the initial reflex reaction from many Austro-German liberals to the defeat was a reassertion of their deep-rooted belief in constitutionalism and a continuation of their fight against Belcredi, rather than a simple profession of loyalty to the Emperor and the Monarchy.

In light of the ongoing war and their lack of real influence in government and Imperial circles, the liberals were in no position to push the Emperor into making a decision in their favour. It was an inappropriate and inflammatory time for liberals to air their 
grievances at being excluded from government and at the suspension of the February Constitution. The Austro-German liberals were blinded by their hopes for a constitutional, progressive, liberal Austria and their indignation at the recent suspension of the constitution. Even the NFP acknowledged the ambiguous nature of the addresses arguing that, in fact it was very patriotic to send them, despite the desperate situation for the Monarchy. ${ }^{29}$ Tactically the pressure was provocative and certainly did not endear the liberals to the Emperor, yet, at the same time, it demonstrated the strength of their convictions and reasserted their influence in public. In stark contrast to the liberals' ill-timed comments, the Archbishop of Vienna Cardinal Joseph Rauscher preached absolute loyalty to the dynasty, duty to the state, adherence to Christian beliefs and called for Austrian patriotism. ${ }^{30}$ In Austria's time of need, the Emperor could not have been presented with a better reminder of the Church's symbiotic relationship with the dynasty and the Monarchy.

Francis Joseph canvassed opinion as soon as news of Königgrätz reached Vienna. On 14 July 1866 there were reports that the leader of the Bohemian constitutionalist (Verfassungstreu) nobles, Carl Auersperg, had attended long audiences with the Emperor and had presented a finished liberal programme that consisted of recalling the 'narrow' Imperial Parliament under the February Patent (i.e. without Hungary), recognizing the Hungarian parliament and allowing both bodies to negotiate common matters. ${ }^{31}$ Auersperg could, however, only speak for his constitutionally-loyal faction in the Bohemian Great Landowners' curia since there was no unified, accepted liberal programme; indeed, there was no single, acknowledged leader of the Constitutional Party. Shortly afterwards, on 17 July 1866 Deák met with Francis Joseph in Vienna. The Hungarian politicians under Deák’s leadership presented a contrast to the impatient Austro-German liberals. Despite pressure from some radical fractions and the threat of a Lajos Kossuth inspired anti-Habsburg 
uprising, Deák was in firm control of Hungarian politics and pursued measured, steady, focussed tactics. When asked what his demands were given the new situation, he uttered the famous phrase 'nothing more than before'. ${ }^{32}$ Deák immediately delegated the negotiations to Gyula Andrássy who proved to be a tremendously skilled politician and an untiring advocate of dualism. In his meetings with Francis Joseph, Andrássy - obviously thinking of Hungary's nationality issues - argued that there should be no autonomy for the Slavs. ${ }^{33} \mathrm{He}$ advised Francis Joseph that 'dualism must be newly built upon the two pillars of the Monarchy, the Germans and Hungarians. They are the elements which above all must be satisfied. ${ }^{34}$ For the Austro-German liberals a 'natural' alliance could be formed with the Hungarians as long as the centralists could accept the dualist structure. There was even some talk of a united conference involving Deák, Andrássy, Jozsef Eötvös, Herbst, Kaiserfeld and Karl Giskra to determine a common stance against federalism and the pro-Slav policies of Belcredi. ${ }^{35}$ Such a conference, however, never took place.

Through the peace negotiations and their aftermath, official government meetings with the Hungarians were continuing. Alexander von Hübner, a conservative diplomat who had been schooled under Metternich and had served as Police Minister for a short time in 1859 , was recalled from his position as ambassador to the Vatican and became heavily involved in the talks in July and August $1866 .{ }^{36}$ Initially, he was reluctant to aid a former revolutionary émigré like Andrássy but he overcame his qualms in the course of negotiations. ${ }^{37}$ The negotiations dragged on. At the end of August Hübner advised the Emperor that it would be premature to involve any representative bodies in such a complicated matter as these negotiations with Hungary - an approach that harmonized well with Francis Joseph's instincts. ${ }^{38}$ When Hübner declined the chance to form a new ministry, Francis Joseph sent him back to the Vatican in September. After his final audience with the 
Emperor, Hübner wrote in his diary that Francis Joseph was now master of the situation. ${ }^{39}$ Following the confusion and disorder of the immediate post-Königgrätz situation, the traditional forms of governance were slowly reasserting themselves. The ministry, the coterie around the Emperor and the Emperor himself were again taking charge of the Monarchy. But their options were limited by a number of considerations; first, the Monarchy's weakened position, second, the balance of domestic forces (which necessitated a resolution with Hungary) and, third, the desire to quickly reassert the Monarchy's 'Great Power' status.

While Hungarian politicians negotiated with the government, the Czech-conservative noble alliance worked behind the scenes. The Bohemian conservative nobles were not prepared to use their contacts at the Imperial Court partly because of the sensitive circumstances but also because they were awaiting a direct invitation from the Emperor. ${ }^{40}$ In governmental circles they relied on Belcredi. In the new situation, František Rieger (leader of the Bohemian Czech nationalists), Alois Pražák (leader of the Moravian Czechs) and Jindřich Clam-Martinic (leader of the Bohemian conservative nobles) met frequently to determine a combined Czech-conservative line. In late July 1866, with war still raging in Bohemia and Moravia, Rieger prepared a set of demands: a commitment to Austria, equality of languages in Bohemia (Czech and German) and a federalist constitution. ${ }^{41}$ Around this time, both Rieger and his father-in-law František Palacký, the notable historian and political leader, were summoned to Vienna for political negotiations. They set off on 23 July 1866, a day after their programme of demands was completed. Rieger spoke informally to the Emperor on 30 July, though with little discernable effect. A more detailed programme was subsequently presented to the Emperor. ${ }^{42}$ It first stated that there should be no more foreign entanglements in Germany and that Austria should concentrate on its domestic organisation 
and constitutional development. In fact, this did happen as a condition of the peace settlement with Prussia, finally putting to rest Czech fears of permanent minority status in a 'Greater Germany' (Großdeutschland) including the western provinces of the Monarchy. In the new circumstances, Rieger asserted that any future constitution should be formed on the basis of the federalist October Diploma and any central parliament and government in Vienna should have a minimum of powers vis-a-vis regional Diets. Each Diet would also have a representative on the government as Court Chancellor. In general, according to the Czech-conservative programme, autonomy and self government should constitute the general principles underlying the governmental system. With respect to the language issue, particularly incendiary in Bohemian, the principle would be one of equality.

While in Vienna Rieger searched for possible allies to the federalist cause and was initially quite successful. He met with a Polish delegation and individual Slovene leaders throughout July and August 1866. Interestingly Rieger was also thinking of possible cooperation with the Autonomists and sent them an invitation on 25 August $1866 .{ }^{43}$ Rieger stressed that this was an epoch making moment and that a clear viewpoint was needed. He met with the Autonomist leaders in Vienna and hoped that there could be a common liberal German-Czech front (and possibly an even wider alliance including the South Slavs and Poles). Rieger was hoping to split the liberal camp and to form a broad coalition for a federalist structure. Nevertheless, the Czech leaders' room to compromise with AustroGerman liberal factions was restricted by their continued loyalty to the Bohemian conservative nobles' alliance.

With Bohemia and Moravia under occupation and centralists in disarray, Kaiserfeld and the Styrian Autonomists had become the clear leaders of the Austro-German liberals. Ideologically and practically, the Autonomists were the only Austro-German liberals who 
could compromise with all the nationalist parties, especially the Czechs nationalists, who posed no threat in Styria or Upper Austria but could still form a majority with the conservative nobles in the Bohemian and Moravian Diets. ${ }^{44}$ At this crucial juncture, however, Moriz von Kaiserfeld's nervous, high-strung character played a significant role. Belcredi described Kaiserfeld as 'moving from place to place with contradictory feelings' and there is much evidence for this. ${ }^{45}$ Kaiserfeld was now in a pivotal position; his support of a liberal, federalist programme would make it a realistic possibility and could point the way towards new multi-national co-operation. While the Autonomists and the Czech nationalist leaders held tentative meetings in mid-August, Kaiserfeld remained extremely concerned about upsetting the centralist liberal groups, especially the German liberal leaders in Bohemia and Moravia. ${ }^{46}$ At the very moment when the Czech nationalists and Autonomists were investigating the possibility of co-operation, their various political alliances and wider concerns drew them back.

Kaiserfeld was very cautious about negotiating with the Czech nationalists due to their association with Belcredi and to German nationalist sentiment in Bohemia and Moravia. Immediately after Königgrätz, the Autonomists' press organ, the Graz-based Telegraf, had called for justice for all peoples, especially in Hungary. ${ }^{47}$

The NFP was non-committal but expressed concern about the future position of the AustroGermans in any possible plan for a liberal, federal Austria. ${ }^{48}$ Now, when many were looking to him for guidance, Kaiserfeld hesitated. Hungary, of course, was an easier issue for Kaiserfeld. He had good connections with Hungarian liberals and even met with the leader Menyhért Lónyay on 14 August 1866. They spoke of a united German-Hungarian liberal conference against Belcredi's pro-Slav federalism but this never eventuated. ${ }^{49}$ Since there was only a scattered, politically insignificant German-speaking population in Hungary with 
few links to the Cisleithanian liberals, conceding power to a Hungarian parliament was less problematic from a German national viewpoint than regional autonomy to Bohemia and Moravia where powerful and significant German-speaking populations faced possible Czech-conservative majorities in the Diets. Moreover, a strong centralist element within the Constitutional Party continued to oppose any major concessions to the Hungarian dualists and refused to countenance any talk of substantial regional autonomy that might benefit the Czech-conservative federalist alliance.

Kaiserfeld called a conference of Austro-German liberals for 9 and 10 September 1866, at the small Styrian town of Bad Aussee. Kaiserfeld wanted to gauge the possibility of liberal unity through a programme of concessions to Hungary and a liberal state based on local and regional autonomy. Personal invitations were sent to prominent liberals and among the delegates who attended were regional liberal leaders Karl Wiser from Upper Austria; Karl Giskra and Eduard Sturm from Moravia; Johann Nepomuk Berger and Julius Alexander Schindler from Vienna and Karl Rechbauer from Styria. Significantly, no representative from Bohemia attended. Initially, there was no final programme, only a set of principles: namely, support for a dualist solution (but no federalism), a return to constitutional life (the February Constitution with its Imperial Parliament), the need to recognise the historical position of Germans in Austria, the continued possibility of a link with Germany and the need for a united German party. ${ }^{50}$

Responses to the Aussee conference varied enormously. The old Presse maintained an attitude of strict centralism and condemned the conference as a concession to the nationalities. ${ }^{51}$ The Fremden-Blatt in a series of detailed articles welcomed the initiative but stressed that the programme needed the support of all liberals and the involvement of ordinary people. ${ }^{52}$ The Czech nationalist leader Rieger came out against the Aussee 
conference, clearly disappointed with Kaiserfeld's strong pro-Hungarian line and his statements against federalism. ${ }^{53}$ The most influential liberal paper, the NFP, generally favoured to the statement of principles but found the manifesto confusing. The Autonomists were traditionally protective of regional Diet rights but if dualism was to be pursued, who exactly would negotiate with the Hungarians: the individual Diets or the Imperial Parliament? The NFP was firmly in favour of the latter. ${ }^{54}$ In general the NFP agreed that dualism was the only real alternative in the present circumstances and that the Constitutional Party should negotiate the terms of the Compromise on behalf of Cisleithania, especially the joint matters. ${ }^{55}$ There were increasing concerns that without an Imperial Parliament providing a forum and moral weight for Austro-German liberal voices, the reorganisation of the Monarchy would be conducted without their participation and possibly to their detriment. 'Should we Austro-Germans remain in the corner without any consideration, our wishes just dying away unheard?' asked the NFP. ${ }^{56}$

Some liberal, federalist voices still pleaded for a multi-national, progressive alliance. In the Telegraf Adolph Fischhof published a series of articles, which appeared shortly after the Aussee Conference. They were subsequently collected in a brochure Ein Blick auf Österreichs Lage (A Look at the Condition of Austria) and provoked much comment. ${ }^{57}$ Fischhof had been a member of the 1849 constitutional committee at the Kremsier/Kroměříž parliament, involving German-speaking and Czech-speaking representatives, which had agreed on a draft constitution. Although no longer an active politician, Fischhof remained in contact with other liberals, published the occasional article and kept abreast of all political developments. Though he was not officially part of the Autonomist group he moved in their circles and published in their newspaper. 
Similarly to Rieger and Palacký, Fischhof saw in the new situation, where the various inter-relationships were much clearer, an opportunity for reconciliation and understanding between the peoples of the monarchy. ${ }^{58}$ For both Fischhof and the Czech nationalists, Austria's exclusion from Germany meant the end to any assumptions from 1848-49 about a 'Greater Germany' which would include the western provinces of the Monarchy but leave a merely personal union with Hungary. ${ }^{59}$ Indeed, Fischhof noted that the Hungarians were even talking of a real union; namely, substantial links between the two halves of the monarchy. He believed that the reform of the Austrian state could now take priority without the distraction of German affairs and without overt German nationalism. Fischhof worried that staying within the bounds of existing institutions would continue the dangerous 'parliamentary battles of the races' with boycotts, rigged elections, heated rhetoric and factional intrigues leading to the nationalities fighting each other. ${ }^{60} \mathrm{He}$ argued for a private conference of party leaders and representatives of the government to agree on the fundamentals of the new constitution - in effect, an informal constitutional convention. ${ }^{61}$ Fischhof evoked the example of Kremsier in 1849 to show that understanding between the nationalities was possible. ${ }^{62}$ Indeed, his suggestion of a private conference of party leaders essentially tried to reproduce the conditions of the Kremsier parliament. Fischhof specifically urged the Autonomist party to take the initiative and to host the conference since they were a 'middle party' - as Germans they had links to the centralists, they could agree with the Czech nationalists on ideological grounds, and their recent stance had gained respect in Hungary. ${ }^{63}$ Rieger was encouraged by Fischhof's suggestion of a preparliamentary conference, as was the Polish leader Agenor Gołuchowski, though both wanted the Autonomists to issue the invitation. ${ }^{64}$ Anton Auersperg (the famous poetpolitician from Carniola) agreed to the meeting but wondered how practical the idea was, 
while Jozsef Eötvös, maintaining Hungarian solidarity with Deák and Andrássy, opposed the idea. ${ }^{65}$ The NFP also opposed Fischhof's proposals arguing that private conferences would undermine the authority of a subsequent parliament. The real issue for the newspaper remained the formation of a great Austro-German liberal party that would join the Autonomists with the Centralists. ${ }^{66}$

The initiative remained with Kaiserfeld. The Autonomists would have to initiate any possible private conference or new multi-national alliance or formation of an integrated liberal party. Yet the Aussee Conference had not created momentum within Austro-German liberal ranks, neither in favour of autonomy and self-administration, nor for contact with other parties about a possible joint liberal programme based on civic and political freedom. Under pressure from the Presse and other centralist critics, Kaiserfeld then performed an astonishing volte-face on 20 September 1866 and disavowed the Aussee Programme. Kaiserfeld now moved towards a more centralist position to the consternation of many in the Autonomist camp who had been contemplating talks with the Czech nationalists. ${ }^{67}$

By the beginning of October, the Autonomists had clearly lost their opportunity of brokering a transnational, multi-party agreement. The centralists were mobilizing as were the Bohemian Germans and no meaningful basis for co-operation with the Czech-conservative, Polish or Slovene-clerical camps had emerged. On 4 October 1866 the centralists gathered at the Viennese residence of the Moravian industrialist Alfred von Skene. Among the fifteen delegates were the former ministers Josef Lasser, Adolf Pratobevera, Franz Hein; former Presidents and Vice-Presidents of the Imperial Parliament Leopold Hasner, Hein (again), Franz von Hopfen; and the leading liberals Eugen Mühlfeld, Karl Giskra and Julius Alexander Schindler - a weighty gathering. Giskra and Schindler had also attended the Bad Aussee conference. Kaiserfeld was invited but declined to come, citing his wife's illness. His 
close collaborator Karl Rechbauer was not invited. ${ }^{68}$ Significantly, the leader of the Bohemian-German liberals Eduard Herbst remained in Prague. ${ }^{69}$ A committee including Hasner and Pratobevera was delegated to prepare a programme. The influential centralists refused to concede to the Autonomists' viewpoint. ${ }^{70}$

On 7 October 1866 Eduard Herbst hosted a meeting of Bohemian Germans in Prague and called for a general conference with representatives from all fractions of the German liberal spectrum. ${ }^{71}$ Somogyi has suggested that Herbst was not in complete agreement with the centralist meeting in Vienna and, considering the Bohemian German position as a minority in the Bohemian Diet, was more receptive to Kaiserfeld's dualist position. ${ }^{72}$ In all probability he and the Bohemian Germans were holding back, staying united and waiting to follow the best course in order to protect their position in Bohemia. The NFP report of the meeting in Prague's German Casino suggests that Herbst had reservations about both the Vienna meeting and about Kaiserfeld's conciliatory stance towards the Hungarians, stating the old assumption that dualist concessions were based on Austria being involved in a 'Greater Germany' ${ }^{73}$ In the new situation, the Bohemian German liberals now assumed the key position from the Autonomists within the Austro-German liberal camp. By maintaining discipline among the approximately 40 Bohemian German liberals who had sat in the Imperial parliament, Herbst held the balance of power between the centralist and the Autonomist wings.

Herbst's primary concerns were the protection of Bohemian German interests, the prevention of Belcredi's federalism and the installation of realistic, centralist constitutionalism based on the February Patent. On 18 October 1866, the five man centralist committee under Hasner and Pratobevera presented its draft programme: the restoration of the February Patent, the calling of the full 'wider' Imperial Parliament (i.e. including 
Hungary) and the maintenance of state unity. ${ }^{74}$ In response, the Telegraf noted that German nationalist solidarity and recognition of the February Constitution were common causes, but the time for an ideal 'integrated, constitutional Austria' was past and something more was required. ${ }^{75}$ A draft programme from the Aussee conference was in wide circulation at the time, though the final document was only published on 17 November $1866 .^{76}$ It emphasised one goal which could bring the peoples of Austria together: personal, civic and political freedom. ${ }^{77}$ The basis of this free Austria, according to the Aussee programme, would be the autonomous administrative commune along with extensive powers for the Diets which would allow national development. Hungarian rights were recognised but common matters should be controlled by a directly elected common parliament. Any negotiations with Hungarian delegates should, according to the programme, be through the February Patent's Imperial Parliament. Events, however, had progressed since the Aussee conference and there was little likelihood that all factions of the Constitutional Party would agree to its programme. Around this time, Fischhof continued advocating private conferences of the party leaders and a search for common interests but he was an increasingly isolated voice. ${ }^{78}$ In effect, the range of possibilities was being reduced by the reassertion of traditional liberal factions, though the overall situation favoured the dualist viewpoint of Kaiserfeld's Autonomists.

Herbst and his Bohemian Germans now faced two options: the centralists' demands for an integrated state with minimal concessions to the Hungarians, or Kaiserfeld's amended position which accepted a dualist construction with the implicit securing of German hegemony over the Western half of the monarchy. There was little possibility of reconciling the two views as evidenced in an article by the leading centralist Alfred von Skene in the Presse on 27 October 1866. Skene and the centralists portrayed themselves as the protectors 
of the Austrian state and of German speakers in mixed areas, drawing a sharp distinction between their centralist views and the provincial-oriented German nationalism of the Autonomists. ${ }^{79}$ This clear disunity in the ranks of the Austro-German liberals, lamented the NFP, contrasted unfavourably with the discipline of the Czechs, Poles and Hungarians. ${ }^{80}$ Faced with Austria's exclusion from Germany, Czech-conservative supremacy in the Bohemian Diet and continued Hungarian intransigence to any form of centralism, Herbst began moving towards Kaiserfeld's camp and acceptance of a possible compromise with the Hungarians. $^{81}$

The appointment of Ferdinand Beust as Foreign Minister on 30 October 1866 brought a fundamental change to the situation. Beust's appointment was not greeted with approbation in Austria; most liberals did not want a foreigner in the most prestigious ministerial position. ${ }^{82}$ Yet he was a potential ally, one who was both close to the throne and had a reputation as a political progressive. Though officially only Foreign Minister, Beust interpreted his remit as including internal matters, especially since the monarchy's international position depended on settling its domestic uncertainties. Beust quickly concluded that the Hungarian question had to be resolved and was soon won over by Andrássy's arguments for dualism based on German hegemony in the West and Hungarian hegemony in the East. ${ }^{83}$ The scene was set a united Austro-German liberal position based on a Herbst-Kaiserfeld axis and an acceptance of a dualist compromise with Hungary. 
Empire nineteen Diets would be meeting - seventeen in Cisleithania plus the Hungarian and Croatian parliaments - and this was the first opportunity for representative bodies to contribute to the debate on the Monarchy's future. It was common practice for representative bodies to draft an address of thanks to the Emperor at the start of a session and in the $1860 \mathrm{~s}$ these address debates were taken very seriously. They provided a forum for wide-ranging debates about general principles and goals, while presenting an opportunity to communicate the Diet's wishes to the Emperor. At the beginning of the sessions in late 1866, nearly all Diets would take the opportunity to put forward their point of view in addresses to the Emperor. Indeed of the seventeen in Cisleithania, eleven sent addresses, including majority and minority addresses from Bohemia and Galicia, while six (Carniola, Tyrol, Dalmatia, Goerz, Trieste and Vorarlberg) declined the opportunity. The address debates accelerated two developments. First, they sharpened the divisions between opposing political groups, especially between the German and Czech nationalist politicians in Moravia and Bohemia. Second, they emphasised the need for unity in Austro-German liberal ranks and focussed attention on the shared beliefs underpinning the different liberal factions.

The Lower Austrian Diet was the first to debate an address on 26 November 1866, it set the tone for the general Austro-German liberal position. ${ }^{84}$ The address emphasized what united the liberals - outrage at the suspension of the constitution, a desire to revive the February Patent and vigorous assertions about the 'German' contribution to Austria - with few specific remedies and no mention of the differences between centralists and Autonomists. The address began with the obligatory expressions of loyalty and patriotism towards the Emperor but quickly painted an alarming picture of the Empire after the suspension of the constitution in September 1865. Provocative phrases such as 'growing fissures and weakness in Austria' and 'corroding pessimism' were used to emphasise the 
consequences of Belcredi's non-constitutional government. ${ }^{85}$ In such a situation the Lower Austrian Diet (and the population it represented) looked to the Emperor to draw together the Monarchy's strength through the 'speedy reinstatement of constitutional conditions'. The draft address implicitly accepted dualism by advocating an understanding with Hungary and by admiring the restoration of the Hungarian constitution (presumably the calling of the Hungarian parliament). Andreas Zelinka, who was also the Mayor of Vienna, defended the position of Germans in Austria, stating that '[f]or centuries the only binding element has been German culture and language, which has combined the different nationalities on socalled neutral ground'. ${ }^{86}$ Julius Alexander Schindler, a respected writer and Alma Mahler's favourite uncle, echoed these sentiments: 'Austria is a cosmopolitan work of German power and culture; the German was and is the most loyal Austrian, he does not recognise any separatism' ${ }^{87}$ Pratobevera gave the final speech. He appealed to common liberal wishes, '[w]e want a constitutional, a truly constitutional unified Austria (Bravo!). We want the revitalization of the Empire ... ${ }^{98}$ The NFP hailed the Lower Austrian address debates as an exemplary parliamentary discussion carried out at a high level, comparable to what one may hear in London or Paris. ${ }^{89}$ One week later the liberal majority in the Upper Austrian Diet presented an address which similarly called for the reinstatement of the constitution. ${ }^{90}$ On the same day the Salzburg Diet presented its address. There was no debate and it was unanimously supported. The address repeated the calls for the reinstatement of the constitution and the involvement of a representative body in government decision-making. ${ }^{91}$

The most contentious address debates took place in the Moravian and Bohemian Diets where the German nationalist representatives were in the minority due to the composition of the Great Landowners' curia. The Moravian debate started on 4 December 1866 and lasted for three days. The majority address supported by the Czech nationalists and 
conservative nobles referred to the federalist October Diploma as the basis for any future organisation of the Monarchy, while the Hungarian dualist proposals were treated with caution..$^{92}$ The minority address was written by Karl Giskra, one of the leading centralist liberals in the 1860s, who gave an impassioned speech defending the February Patent as the basis of legal representation in Austria. He reiterated that the Imperial Parliament was the only correct forum for considering any Compromise with Hungary. ${ }^{93}$ Despite a centralist tendency in Moravian-German liberal ranks, the wording of the minority address was not overly centralist, indeed it argued that the respective representative bodies should arrive at a speedy agreement over Hungary. ${ }^{94}$ Centralist sentiments were, however, not far from the surface. The arch-centralist Alfred von Skene attacked his Moravian conservative and Czech nationalist opponents, describing them as small minded and lacking commitment to the Austrian state. ${ }^{95}$ Skene still dreamed of a centralised state:

... it will be one Austria, with unified interests. And once the unity is there, the rights of citizens will come - they will remain in place and, in any case, will bring equality - and then absolutism, as it is now, will be buried forever. (Bravo! Left). ${ }^{96}$

Skene's vision left no room for compromise with Hungarian demands; it favoured a strong government and a central parliament which, together, could realise the Austrian state idea, cultivate a sense of belonging but also allow space for citizens to develop. ${ }^{97}$ These were the ideals of many Austro-German liberals and Skene was very reluctant to compromise them. ${ }^{98}$ Skene's speech prompted Egbert Belcredi to defend the majority address. ${ }^{99} \mathrm{E}$. Belcredi, who had sat on the address committee, had not wanted a substantive address, believing instead that the circumstances demanded a simple expression of loyalty. In his speech, E. Belcredi described the February Patent as bringing four wasted years since there had never been a real Imperial Parliament due to the various boycotts. On the other hand, he 
argued, the October Diploma had never been allowed to fully develop; it had protected the rights of each crown land and should constitute the basis of any Compromise with Hungary. ${ }^{100}$ Alois Pražák, the long time leader of the Moravian Czech nationalists and later Justice Minister in the 1880s, concluded the debate reiterating the majority's arguments for crown land autonomy and support for the October Diploma. He too criticised the February Patent's Imperial Parliament as an 'impossible experiment' ${ }^{\text {' }}{ }^{11}$ In the end, no draft attained a majority and a simple address of loyalty had to be sent. ${ }^{102}$ The debates in Moravia widened the gap between German and Czech nationalists while also highlighting the competing conceptions of the Monarchy's political system.

The address debate in Bohemia followed shortly after and was even more heated. The majority address drafted by Rieger and Clam-Martinic, was similar to the one in Moravia, arguing for autonomous development, more powers to the crown land Diets and adherence to the October Diploma. ${ }^{103}$ Self administration, the federalists argued, would lead to renewed political consciousness and state strength. Finally, the draft made a plea for equality among the nationalities of the Monarchy. The minority address, drafted by Herbst, blamed the Monarchy's woes on Richard Belcredi's ministry and its 'policy of suspension'. ${ }^{104}$ Without oversight and control from the Imperial parliament, the address opined, the government had exercised free reign to pursue its policies and instead of reform these had produced stasis and financial deterioration. The result was widespread 'pessimism'; a word also used in the Lower Austrian and the Moravian minority addresses. In conclusion, the minority address made three demands: a responsible government system, the restoration of constitutional life and the convening of the February Patent's Imperial parliament as the constitutional representative body of the people. 
In the debates, Ignaz von Plener, the Finance Minister in Schmerling's cabinet, presented the centralists' viewpoint. He stressed the seriousness of the situation, especially for foreign relations, and stated that any compromise with Hungary would involve a weakening of the Austrian state. ${ }^{105}$ Ottokar Zeithammer outlined the Czech nationalist view in the debates, which was strongly Austro-Slavic; that the Habsburg Monarchy was an umbrella state protecting the small peoples caught between Germany and Russia. ${ }^{106}$ Jindřich Jaroslav Clam-Martinic, the long-time leader of the Bohemian conservative nobles, absolved the Belcredi government of responsibility for the military defeat and defended its suspension of the constitution. Suspension had attempted to solve the failure created by the February Patent, he argued, and sought to base the Empire instead on 'the understanding of people under the balancing rule of the Crown'. ${ }^{107}$

Herbst rose to the challenge and in a desperate time for the Bohemian-German liberals, gave one of his greatest speeches. He began by arguing that in the changed conditions the monarchy needed a strong state above all. ${ }^{108}$ While the Czech nationalists and conservatives had argued that the federal principle strengthened the state, Herbst appealed to the course of history to show that every federal state had eventually moved towards a unified state. ${ }^{109}$ If an organism is divided into nineteen separate parts then the organism is not strengthened, argued Herbst. He next ridiculed the legal arguments of the Bohemian state rights proponents; theatrically reading from Ferdinand II's 1627 Landesordnung that had reduced the Bohemian Diet's privileges. Given the present circumstances, Herbst continued, the ministry and the bureaucracy had to be controlled by a central representative body. ${ }^{110}$ This had been the problem with the Belcredi ministry, argued Herbst; there had been no control or oversight from representatives of public opinion. ${ }^{111}$ Thus, Herbst concluded, the 
Imperial Parliament should be called to represent the people in the negotiations with Hungary. ${ }^{112}$

Clearly Herbst, Giskra and the bulk of the Austro-German liberals were moving away from any ideas of strict centralism and towards recognition that a Compromise with Hungary was unavoidable. The basis of a united liberal approach was forming out of the address debates and the behind-the-scenes manoeuvring. The liberals would accept the Compromise with Hungary - as pushed by Kaiserfeld and the Autonomists - but without wide-ranging regional autonomy, which could have been the basis for a Czech nationalistAutonomist alliance. There would also be a powerful, constitutional Imperial Parliament, so important for Herbst, Giskra and their supporters, but it would be limited to Cisleithania, not the entire empire. Finally, the liberals asserted a special role for Germans and their language within the Habsburg Monarchy. This consensus amongst liberal factions was confirmed in the Styrian Diet's address debates. On 10 December 1866, Kaiserfeld emphasised two common points - a return to constitutional government and the continued hegemony of Germans in Austrian public life.

Only a constitutional Austria or nothing more! ... a state which assumes 'Great Power' status and is also constitutionally governed, can only fulfil those two conditions ... if it has at the very least one nationality taking the undisputed leadership in political and diplomatic affairs. ${ }^{113}$

According to Kaiserfeld, the leading nationalities could only be the Germans in the West and the Hungarians in the East. The Imperial Parliament should be called into session, a parliamentary government formed and negotiations begun with the Hungarians for a constitutional, liberal, dualist monarchy. ${ }^{114}$ His colleague Karl Rechbauer similarly wanted the constitution to secure German existence, culture and education. ${ }^{115}$ Four days later the 
Carinthian Diet agreed on a similarly-worded address. ${ }^{116}$ Crucial support at this time came from Hungarian politicians. The circle around Deák and Andrássy had from the start wanted the approbation of a Cisleithanian representative body as extra insurance for any negotiated Compromise. $^{117}$

At the same time the Diets with federalist majorities continued to assert their respective stances against the February Patent and the central state. The Istrian Diet, with an Italian nationalist majority, debated its address on 4 December 1866 and called for autonomy at a local and regional level. ${ }^{118}$ Similarly when the Galician Diet debated its address on 7 December 1866, Zygmunt Rodakowski for the Polish nationalist majority argued that centralisation was not conducive to freedom and progress and that regional autonomy should be pursued. ${ }^{119}$ Belcredi had installed the Polish leader Agenor Gołuchowski as Governor in Galicia on 23 September 1866 and held out the promise of substantial Polish autonomy. ${ }^{120}$ The Ruthenians, who submitted a minority address, wanted equality in Galicia and supported a return to the February Patent. ${ }^{121}$

Circumstances were, however, turning against the federalists. The Austro-German liberals finally showed some unity, their Hungarian liberal counterparts sent encouraging signs and Beust believed that dualism was the only viable way forward. The Austro-German liberals were still not included in any official Compromise talks, though both Beust and Andrássy sounded them out about their demands in the event of a dualist structure. Francis Joseph, too, seemed now to lean towards the Hungarians and the Austro-German liberals. ${ }^{122}$ On an earlier visit to Prague, Francis Joseph had met with Rieger and Clam-Martinic, who stated their expectation for a Bohemian Compromise similar to any Hungary received. ${ }^{123}$ When the Czech nationalist delegation had an audience with the Emperor on 17 December 1866 to present their majority Diet address he acted in a very cold manner. ${ }^{124}$ Despite his 
reservations, the Emperor could ultimately accept dualism since, as Belcredi noted in his memoirs: 'two independent parliaments are not dangerous at all and even desired by the Crown, since what the Emperor cannot obtain from one parliament, can be achieved from the other'. ${ }^{125}$ This juggling between institutions and manipulation of the dualist system would be a feature of subsequent decades.

The tide was running against the federalists but Belcredi had not yet given up hope. After the Diet debates he allegedly stated to a friend that: "Now, you see, I am still alive."126 On 23 December 1866 he persuaded the ministerial council, including Beust, to call an extraordinary Parliament coupled with new elections for the Diets. This would not be the Imperial Parliament under the February Patent but simply an extraordinary meeting of crown land representatives to consider the Compromise with Hungary. The terminology implied that it would not meet regularly. ${ }^{127}$ An official patent issued on 2 January 1867 did not specify how the Diets would elect deputies to the Parliament (Belcredi allowed each Diet to decide either by curia voting or by majority voting). The latter method potentially meant the complete exclusion of Austro-German liberal representatives from Bohemia, Moravia, Carniola and possibly also in Tyrol as well as the exclusion of their allies, the Ruthenians, from the Galician Diet. In all probability, Belcredi's extraordinary Parliament would have produced a strong federalist-Slav-conservative majority. ${ }^{128}$ Indeed, some calculations estimated the federalists as having at least 114 representatives and the German liberals only $89 .^{129}$

Just as the Austro-German liberals were conceding the Compromise with Hungary and coming together as a united political force, they now faced the possibility of a federalistSlav-conservative parliament negotiating the future of Austria with the Hungarian parliament. All German liberal discussions of dualism had rested on the presumption of joint 
German-Hungarian hegemony and of a regular central parliament for the Cisleithania Belcredi’s extraordinary Parliament was a direct challenge to this thinking. Finally, after months of juggling between different alternatives, the Emperor had to make a decision between two clear alternatives - Beust's dualism based on German and Hungarian hegemony or Belcredi's more federalist procedure involving all the regional Diets. The terms and conditions of these alternatives had been determined by the manoeuvring, pressure and demands of the various political groupings, including the Austro-German liberals who had originally appeared in weak position. The endgame to the Compromise would be played out between Beust and Belcredi in the presence of the Emperor.

\section{$* * *$}

Belcredi's January Patent for the extraordinary Parliament sealed the convergence of the Austro-German liberals. They were now completely united, fighting for their February constitution and their position in the monarchy. ${ }^{130}$ Rechbauer summed up the mood best when he stated that the calling of the extraordinary Parliament had broken the apathy of the people. ${ }^{131}$ On 13 January 1867 the leaders of all the German liberal fractions met at Adolf Pratobevera's residence to discuss their strategy towards Belcredi’s extraordinary Parliament. Delegates from all factions attended including Kaiserfeld, Karl Rechbauer, Ignaz von Plener, Anton von Auersperg, Ignaz Kuranda, Alfred Skene, Josef Lasser, Karl Wiser while Herbst and Giskra sent letters of support. The resolutions from the meeting demanded a boycott of the extraordinary Parliament and the calling of the legal Parliament under the February Patent. ${ }^{132}$ In the face of stark realities the liberals concentrated on their essential points of agreement. The centralists were prepared to accept dualism and the Autonomists 
were no longer entertaining federalist ideas. The basis of the Constitutional Party's next decade had been laid.

Beust and the Hungarian delegates finalised the terms of the Compromise on 8, 9 and 10 January 1867. After concluding the Compromise with the Crown's representatives, the NFP reported a rumour that the Hungarian delegates had also met the German liberals to reach an agreement.

If our information is correct, once the German Constitutional Party decides to discard the points in the February Patent which contradict the Hungarian constitution, then the Compromise question can be considered completely settled ... Would the Slavs in alliance with the Government be strong enough to resist a German-Hungarian alliance ${ }^{133}$

The Hungarian liberals had access to the Austro-German liberal meetings and both sides made a conscious effort to understand each other. ${ }^{134}$ Deák’s party, especially Andrássy, opposed any involvement of Cisleithanian representatives in the substantive terms of the Compromise but wanted the support of the German liberals for the concluded agreement. ${ }^{135}$ With the essential terms of the Compromise finalized the main issue was how to bring it into effect. There were three possibilities for the Cisleithanian side: either it could be decreed by the Emperor, or it could be debated and ratified by Belcredi's extraordinary Parliament, or it could be confirmed by the February Constitution's 'narrow' parliament. Privately, Kaiserfeld told Belcredi that a decree should be used as this would be the quickest method. ${ }^{136}$ Some Austro-German liberals were now prepared to accept the Compromise as a fait accompli without any input from Cisleithanian representatives, provided they were given their 'legitimate' Parliament under the February Patent. ${ }^{137}$ 
Ultimately, it was still the Emperor's decision about how to realise the Compromise. Beust was of the opinion that the extraordinary Parliament would never happen since the German parties were refusing to co-operate. ${ }^{138}$ In two lengthy memoranda dated 25 and 26 January 1867 Beust set out his position to Francis Joseph. Beust argued for the end of Belcredi's suspension policy which had been mercilessly attacked by the independent newspapers. ${ }^{139}$ There should be a return to constitutional life under the February Patent, Beust wrote, since any attempts at absolutism would face a barrage of negative public opinion. Foreign policy calculations were also of great importance to Beust since a constitutional, German-led Austria could combat pan-Slavism and possibly act as an attractive, progressive counter-weight to Prussian dominance in Germany. The southern, Catholic, German states in particular were wary of Bismarck's Prussia in the new arrangements in Germany and might be attracted to a liberal German-led Austria, he noted.

The elections for Diets, which would in turn send delegates to the extraordinary Parliament, took place in late January and early February 1867, though all political parties were looking to Vienna for some direction. Beust leaked the contents of a meeting with Andrássy which questioned the idea of the extraordinary Parliament and implied that the elections would not be very meaningful. ${ }^{140}$ Combative to the end, Belcredi published an anonymous pamphlet which pleaded for German involvement in the Diet elections and the extraordinary Parliament arguing that they were to facilitate constitutional life. ${ }^{141} \mathrm{He}$ also put immense official pressure on bureaucrats to vote in a federalist manner and hoped to influence the Great Landowners in Bohemia, Moravia, Galicia and Carniola to vote for the government list. ${ }^{142}$ For the Austro-German liberals the situation had crystallised into a simple quid pro quo - acceptance of the government negotiated Compromise in return for 
constitutional life in Cisleithania based on the February Patent. Giskra's election speech in Brünn/Brno made this clear:

The Compromise with Hungary is, I assert, absolutely necessary for the power status and development of Austria ... [After defending the February Constitution and attacking the extraordinary Parliament, Giskra concludes:] A constitutional basis for the Emperor and the Empire! (loud and long applause). ${ }^{143}$

Moravia was one the strongest centralist-tending regions in the Monarchy and if their leader was openly prepared to concede the Compromise then the centralist wing of the liberals would no longer openly oppose an agreement with Hungary.

At an informal meeting on 27 January 1867 the Emperor informed Belcredi that he had decided to follow Beust's plans; namely, a decreed Compromise and an 'ordinary', 'narrow' Parliament based on the February Patent to ratify it (but not to negotiate or fundamentally amend the concluded agreement). ${ }^{144}$ While Belcredi defended his desire for a longer process involving consultation with different regional crown lands, the Emperor now wanted to push decisions and to stabilize the Monarchy. The Emperor also confirmed that he was prepared to be crowned King of Hungary. Despite already making up his mind, Francis Joseph scheduled a final discussion of the matter at the ministerial council meeting of 1 February 1867. Just prior to the meeting, Beust made his viewpoint clear to Belcredi, 'if I have the Germans and Hungarians for me, I don't have to fear the opposition and enmity of the other nationalities!' ${ }^{145}$ There were echoes of Andrássy’s (and perhaps Kaiserfeld's) influence in this statement. On 1 February 1867 Francis Joseph chaired the meeting that debated the options and after due consideration he decided for Beust's approach. ${ }^{146}$ Two days later Belcredi resigned as a Minister-President and State Minister and Beust added this position to his existing post of Foreign Minister. 
A few outstanding matters needed to be addressed to facilitate the new arrangements. The Polish Governor Agenor Gołuchowski was immediately called to Vienna and consulted about the possibility of the Poles attending the February Patent parliament and thus participating in sanctioning the Compromise agreement. Beust had been speaking with conservative Polish nationalist leaders since early January 1867 and could now offer them considerable autonomy in Galicia for administration, justice and education. In addition, the elections to Diets that would choose deputies to the extraordinary Parliament had to be stopped and the 'ordinary' Parliament elected in accordance with the February Patent. This was done by a patent of 4 February 1867. In the Diets of Bohemia, Moravia and Carniola, which had federalist majorities, new elections were called with the expectation of achieving a centralist, constitutionalist majority. The Monarch's direct representatives applied pressure through official channels to obtain votes in the Great Landowners curia in favour of the Constitutional Party. ${ }^{147}$ The road to the 1867 constitutional laws, the Burger Ministry and a constitutional Cisleithania now lay open.

There are four points to be made in conclusion: two in relation to the Austro-German liberals and two in relation to the wider political situation in the Monarchy. First, for the Austro-German liberals the events of 1866 and 1867 meant the gradual convergence of different factions around the acceptance of dualism as the default structure of the Monarchy. The limits of Austro-German liberal ideological flexibility had gradually become apparent. By sacrificing centralism and acquiescing to dualism, the liberals appeared to secure their core demands for constitutional government and a hegemonic role for German-speakers in at 
least the Western half of the Monarchy. Austria's political exclusion from the new Germany and the mooted possibility of a federalist Cisleithania had greatly affected the liberal camp. ${ }^{148}$ In the wake of Königgrätz it was clear from the November-December Diet address debates that German national sentiment within the Austro-German liberal camp was slowly moving away from a belief in an expansive cultural and political All-German sphere towards an increased concern at the position of German-speakers within the Habsburg Monarchy. ${ }^{149}$ In general, for the German-speakers in the Habsburg Monarchy there was a turn inwards and towards a defence of Austro-German interests which was gradual, differentiated but significant. After initial uncertainty, the Constitutional Party had re-founded itself by acknowledging the necessity of dualism and by focusing its attentions on achieving its constitutional goals and the protection of Austro-German hegemony in Cisleithania.

Second, through the press, political programmes and representative bodies, the Austro-German liberals expressed their views and forced an open, public discussion about the future of the Monarchy. By their vigour and seriousness, the liberals slowly built an open, liberal society yet, at the same time, also facilitated the articulation of competing viewpoints - whether based on nationality or conservatism - and often drew the enmity of the Emperor. These developments came to fruition in 1879 when the Emperor turned to the conservative and Slav federalist parties to form a constitutional government. The liberal articulation of their beliefs had facilitated sweeping achievements in the 1860 s and 1870s, not only in constitutional government, legal framework and institutional reform but also in the basic terms of political discourse and the general acceptance of constitutionalism, civil rights, justice, parliament, education, responsible government, progress and legal equality. In the formative decades of constitutional and parliamentary life the Austro-German liberals pushed and prodded the traditionally conservative Monarchy towards fundamental and long- 
lasting reforms, even if their opponents often benefited from those reforms in the long run. ${ }^{150}$ The months after Königgrätz saw a crucial period of redefinition in this ongoing, evolving, protean Austro-German liberal project to create a modern Austria.

Third, the balance between political groupings within the monarchy was clearly a delicate one. There were many possible constellations and frequent changes both within and between groupings in terms of power and influence. The Austro-German liberals did not fully grasp this. Given their traditions of Josephinist state service and belief in German culture, they assumed that they were indispensable to the running of the monarchy and that they deserved a privileged position. Austro-German liberal hubris cost them dearly in the 1880s when Eduard Taaffe's conservative-Slav coalition proved that the Monarchy could be constitutionally 'run without the Germans'. ${ }^{151}$ Hubris blinded the Austro-German liberals to the reality that politics in the Habsburg Monarchy depended on making strategic alliances and maintaining the Emperor's favour. Looking back many years later Skene, who had been a principled liberal critic throughout the 1860 s, observed to Schmerling that 'we were then really unintelligent and inexperienced men, now we regret it all' ${ }^{152}$ Even the Hungarian liberals who were the best placed in 1866-67 recognized that they still needed the agreement of the Austro-German liberals if their dualist system would be realized. The Czech nationalist camp similarly recognized the need for allies, such as the Autonomists and/or Poles. When reflecting on events decades later, Rieger blamed his erstwhile allies, the Poles, for accepting Beust's offer of regional autonomy. ${ }^{153}$

Finally, Francis Joseph showed again that he would remain sole arbiter of the monarchy's important matters. He was prepared to make individual compromises with different groupings but did not want to promote a unified stance among the nationalities, particularly not a multi-national liberal alliance. Adolph Fischhof's dream of a conference of 
leaders drawing up an agreed liberal constitution was his monarch's nightmare. Francis Joseph never seriously considered a constitutional convention where all parties could hammer out an agreement each could live with. Instead, he preferred to retain as much power as possible, to let the political situation drift, possibly even to allow the parties to harden their positions and then to mediate matters either personally, through trusted representatives or through his government. Many possible points of agreement and grounds for co-operation among different parties quickly disappeared amidst the frantic manoeuvring for favour and second-guessing of the Monarch's prevailing opinion. Any non-sanctioned alliance amongst political groupings could have hamstrung the Monarch and created a powerful rival for political authority within the Empire. The old Habsburg tactic of 'divide and rule' was continued into the dualist era since, as Belcredi had noted, there remained considerable flexibility and ambiguity in its institutions and workings. ${ }^{154}$ Within this complex matrix of political groupings and institutions the Austro-German liberals constituted an important component. Ultimately in 1866-67 and indeed throughout his reign, for Francis Joseph the most important considerations were the Monarchy's status as a 'great power' and the well-being of his military. ${ }^{155}$ In this respect the Compromise of 1867 largely achieved these goals. ${ }^{156}$ In return Francis Joseph was forced to accede to the liberals' principal demands which, then, laid the foundations for a new constitutional state and society.

\footnotetext{
${ }^{1}$ Haus-, Hof- und Staatsarchive (HHStA), Nachlass Adolf Pratobevera, carton 13, entry dated 7 October 1866.

${ }^{2}$ Place names are often contentious when writing about Central Europe. Where there is a widely accepted English place name (eg. Vienna, Prague, Budapest, Styria, Carinthia) I have used the English version,
} 
otherwise I have given the main variants in the first instance followed by the German place name - since this article is about the Austro-German liberals.

${ }^{3}$ For the formation of the 'traditional' interpretation the works of Richard Charmatz and Joseph Redlich were particularly influential. Richard Charmatz, Deutsch-österreichische Politik. Studien über den Liberalismus und über die auswärtige Politik Österreichs (Leipzig, 1907); Richard Charmatz, Österreichs innere Geschichte von 1848 bis 1907, 2 vols. (Leipzig, 1911), Richard Charmatz, Das politische Denken in Österreich (Vienna, 1917), Richard Charmatz, 'Der österreichische Liberalismus: Seine Geschichte und sein Sterben', Die Zukunft 3 (1956): 75-9 and Joseph Redlich, Das österreichische Staats- und Reichsproblem. Vol. 2: Der Kampf um die zentralistische Reichsverfassung bis zum Abschlusse des Ausgleiches mit Ungarn im Jahre 1867 (Leipzig, 1926). 2: 673-5. Later works by Georg Franz and Karl Eder continued to be generally critical of the liberals. Georg Franz, Liberalismus. Die deutschliberale Bewegung in der Habsburgischen Monarchie (Munich, 1955): 148. Karl Eder, Der Liberalismus in Altösterreich - Geisteshaltung, Politik und Kultur (Vienna, 1955): 237. Recent work has been more balanced recognising both the enormous contribution of the liberals and their limitations. John Boyer, Political Radicalism in Late Imperial Vienna: Origins of the Christian Social Movement 1848-1897 (Chicago, 1981): 1-39 and especially Pieter Judson, Exclusive Revolutionaries. Liberal Politics, Social Experience and National Identity in the Austrian Empire, 1848-1914 (Ann Arbor, 1996): 1-10 and 267-72.

${ }^{4}$ Éva Somogyi, 'Pläne zur Neugestaltung der Habsburger Monarchie nach dem Preußisch-Österreichischen Krieg von 1866', Acta Historica Academiae Scientiarum Hungaricae 21 (1975): 16-50 and Éva Somogyi, Vom Zentralismus zum Dualismus. Der Weg der deutschösterreichischen Liberalen zum Ausgleich von 1867 (Budapest, 1983): 58-93 both outline the internal machinations within the Austro-German liberal movement well but do not discuss the addresses of Town Councils or Diets, which provided crucial forums for liberal manoeuvring. Judson, Exclusive Revolutionaries $105-115$ is particularly good on the January 1867 elections but does not investigate the immediate post-Königgrätz situation in detail. There is a short discussion of the various liberal factional meetings in Franz, Liberalismus: 244-9. Two classic works from the first half of the twentieth century concentrate on the high-level negotiations leading up to the Compromise. Louis Eisenmann, Le Compromis Austro-Hongrois de 1867 (Paris, 1968) and Joseph Redlich, Das österreichische Staats- und Reichsproblem Vol. 2. 
${ }^{5}$ The term Cisleithania denotes the non-Hungarian lands which were represented in the Imperial Parliament.

${ }^{6}$ See the suggestive comments in Redlich, Das österreichische Staats- und Reichsproblem, 1: 132. According to the liberal world-view, this hegemony would not be based on specific measures; rather it would be the 'natural' outcome of various factors: the prevalence of the German language in the bureaucracy and military, the historical role of German-speaking elites in building the Austrian state and the prestige of German culture and science. So, for example, the 1867 December Constitution drafted by the liberals contained universalist language and reflected the belief that a constitutional, progressive state would automatically be dominated by German speaking elites.

${ }^{7}$ See the assessment in Die Presse, No. 58, 28 February 1861 and No. 61, 3 March 1861. The Imperial Parliament was elected by curia voting - the Great Landowners, Chambers of Commerce, town and country on a regional basis. The government's influence, particularly in the Great Landowners' curia, was often decisive in elections. The representatives from Hungary, Croatia and Lombardy-Venetia never attended the February Patent's Imperial Parliament. In 1863 the Czech and conservative noble representatives from Bohemia and Moravia decided on non-attendance.

${ }^{8}$ For example in a letter from the Bohemian Alois Brinz to Bartholomäus Carneri dated 22 November 1865. Brinz was asked whether he now belonged to the Autonomists because of his opposition to Belcredi's suspension policy. He was non-committal but stated that the Bohemian liberals agreed with the autonomists. Paul Molisch (ed.), Briefe zur deutschen Politik in Österreich von 1848 bis 1918 (Vienna and Leipzig, 1934): 21.

${ }^{9}$ Gary Cohen, The Politics of Ethnic Survival: Germans in Prague, 1861-1914 (Princeton, 1981): 60-3 and Otto Urban, 'Der böhmische Landtag' in Helmut Rumpler and Peter Urbanitsch (eds.), Die Habsburger Monarchie 1848-1918. Vol. 7: Verfassung und Parlamentarismus. No. 2: Die Regionalen Repräsentativkörperschaften (Vienna, 2000): 2003-23.

${ }^{10}$ See the reference in Lothar Höbelt, 'Das Bürgerministerium', Études Danubiennes 14 (1998) 2: 4.

${ }^{11}$ In an interview with Friedjung, Josef Unger used this phrase to describe Herbst. They had disagreed over executive privilege in the bitter parliamentary debates concerning the Berlin Treaty in 1879. Heinrich Friedjung, Geschichte in Gesprächen. Aufzeichnungen 1898-1919, 2 vols., eds. Franz Adlgasser and Margret Friedrich (Vienna, 1997), 2: 295. 
12 The Autonomists articulated their ideas, as did many political groupings, in the press and brochures of the early 1860s, after strict censorship had been lifted. See, for example, Moriz von Kaiserfeld, Beiträge zu den Tages-Fragen (Graz, 1859), Joseph Kalchberg, Kleine Beiträge zur großen Fragen in Österreich (Leipzig, 1860), Bartholomäus Carneri, Neu-Österreich. Ein Wort über ächten und falschen Constitutionalismus (Vienna, 1861) and Bartholomäus Carneri, Die freie Gemeinde. Ein Beitrag zur wichtigsten Frage unserer Landtage (Vienna, 1863).

${ }^{13}$ Published after Kaiserfeld's death in Die Presse, No. 65, 7 March 1885 'Moriz v. Kaiserfeld'. I have used the spelling of names most commonly used while the individual was alive. So, for example, Moriz (not Moritz) Kaiserfeld and Adolph (not Adolf) Fischhof.

${ }^{14}$ Neue Freie Presse (NFP), No. 504, 25 January 1866, MB. Reprint of the original Pester Lloyd article of 23 January 1866.

${ }^{15}$ As Louis Eisenmann observed, before Königgrätz the Hungarian 15 man committee draft constituted the maximum demands for the Hungarians, after Königgrätz the draft was the minimum. Eisenmann, Le Compromis: 430.

${ }^{16}$ Otto Urban, Die tschechische Gesellschaft 1848-1918, 2 vols. (Vienna, 1994) 1: 235-8.

${ }^{17}$ Urban, 'Der böhmische Landtag': 2009-10 and Jiří Malír, 'Der mährische Landtag' in Rumpler and Urbanitsch, Die Habsburger Monarchie 1848-1918. Vol. 7, 2: 2078-82.

${ }^{18}$ Urban, Die tschechische Gesellschaft 1848-1918. 1: 280-3. For Belcredi’s point of view see Arthur Zimprich, 'Belcredis Versuche einer Föderalisierung der Donaumonarchie (1865-1867)', Ungarn Jahrbuch 2 (1969): 99-138.

${ }^{19}$ For the background see, Ottokar Zeithammer, Zur Geschichte der böhmischen Ausgleichsversuche (18651871). Vol. 1: Von Belcredi zu Hohenwart (Prague, 1912): 8-11 and Urban, Die tschechische Gesellschaft. 1: 284-87

${ }^{20} N F P$, No. 663, 5 July 1866, MB. The NFP continues with the call for a 'radical change of system'. NFP, No. 670, 12 July 1866, MB.

${ }^{21}$ Die Presse, No. 186, 9 July 1866 ‘Adresse um Einberufung des Reichsrathes’. ${ }^{22}$ NFP, No. 672, 14 July 1866, MB. A reply questioning the jurisdiction for such an address was given to the Graz Town Council. See NFP, No. 696, 7 August 1866, MB. As late as October addresses were still being sent 
to the Emperor but were returned with the statement that the address was outside the jurisdiction of the body. See NFP, No. 766, 17 October 1866, MB.

${ }^{23}$ Protokolle der öffentlichen Sitzungen des Gemeinderathes der k.k. Reichshaupt - und Residenzstadt Wien, 10 July 1866 (Vienna, 1866): 1719-20. There is an account give in Annemarie Meixner, Der Wiener Gemeinderat in den Jahren 1864-1868 (Ph.D., diss., University of Vienna, 1975): 190-194 and in Walter Rogge, Österreich von Világos bis zur Gegenwart, 3 vols. (Leipzig and Vienna, 1873), 2:349-50.

${ }^{24}$ Protokolle des Gemeinderathes der Wien, 17 July 1866: 1782-83. See also NFP, No. 626, 18 July 1866, MB.

${ }^{25}$ See Protokolle des Gemeinderathes der Wien, 24 July 1866: 1815-16 for an account given by Mayor Zelinka at a packed council meeting.

${ }^{26}$ Ibid: 1816.

${ }^{27}$ NFP, No. 684, 26 July 1866, MB. Public opinion in Vienna is difficult to gauge but some accounts point to public anger at the government and Belcredi. Eduard Sueß, Erinnerungen (Leipzig, 1916): 164; [Heinrich Pollak], Dreissig Jahre aus dem Leben eines Journalisten. Erinnerungen und Aufzeichnungen 3 vols. (Vienna, 1894), 1: 173 and Jakob Ludwig Heller, Long Forgotten Events from Imperial Austria (Riverside, 2005): 97. ${ }^{28}$ Die Presse, No. 202, 25 July 1866.

${ }^{29}$ NFP, No. 678, 20 July 1866, MB.

${ }^{30}$ Joseph Rauscher, Hirtenbrief (Vienna, 1866): 2. The plea is dated 4 July 1866. See also Joseph Rauscher, Das Jahre 1866. Hirtenschreiben (Vienna, 1866).

${ }^{31}$ Die Presse, No. 202, 14 July 1866. Carl Auersperg was against too many concessions to the Hungarians and was quite centralist in his views. See [Carl Auersperg], Wofür kämpft Ungarn? Zur Klärung der politischen Standpunkte (Vienna, 1866).

${ }^{32}$ Quoted in Zoltan Kramar, The Road to Compromise, 1849-1867: A Study of the Habsburg-Hungarian Constitutional Struggle in its Terminal Phase (Ph.D. diss.., University of Nebraska 1966): 152. See also Eduard von Wertheimer, Graf Julius Andrássy. Sein Leben und Seine Zeit, 3 vols. (Stuttgart, 1910) 1: 216.

${ }^{33}$ Redlich, Das österreichische Staats- und Reichsproblem, 2:506-7.

${ }^{34}$ Quoted in ibid: 505. 
${ }^{35}$ Ferdinand Krones, Moritz von Kaiserfeld. Sein Leben und Wirken als Beitrag zur Staatsgeschichte Österreichs in den Jahren 1848 bis 1884 (Leipzig, 1888): 251-2.

${ }^{36}$ Friedrich Engel-Janosi, Der Freiherr von Hübner 1811-1892. Ein Gestalt aus dem Österreich Kaiser Franz Josephs (Innsbruck, 1933): 184.

${ }^{37}$ HHStA, Sonderbestände, NachlaßAlexander Graf Hübner, diary entry 13 August 1866.

${ }^{38}$ HHStA, Nachlaß Hübner, diary entry 29 August 1866,

${ }^{39}$ HHStA, NachlaßHübner, diary entry 27 September 1866.

${ }^{40}$ Politik, No. 349, 19 December 1905 'Riegers Erinnerungen aus dem Jahre 1866'. For some comment on the conservative nobles' decision see Eisenmann, Le Compromis: 433-34 and Jiří Kořalka, František Palacký (1798-1876). Der Historiker der Tschechen im österreichischen Vielvölkerstaat (Vienna, 2007): 457.

${ }^{41}$ Zeithammer, Zur Geschichte der böhmischen Ausgleichsversuche, 1:12-15. See also Jan Havránek, 'Die tschechische Politik und der Ausgleich von 1867' in Anton Vantuch and L'udovít Holotík, Der ÖsterreichischUngarische Ausgleich 1867 (Bratislava, 1971): 530-33; Somogyi, 'Pläne zur Neugestaltung der Habsburger Monarchie', 43-9 and Rogge, Österreich, 2: 354-5. Die Presse warned that federalism would only increase centrifugal tendencies and lead to the decomposition of the Empire. Die Presse, No. 203, 26 July 1866. ${ }^{42}$ A copy can be found in Zeithammer, Zur Geschichte der böhmischen Ausgleichsversuche, 1: 16-22. Similar arguments can be found in [Anon.], Österreich und die Völker Österreichs im Jahre 1866 (Prague, 1866). ${ }^{43}$ The details can be found in NFP, No. 734, 15 September 1866, MB 'Eine Einladung L. Rieger's'. See also Rogge, Österreich, 2: 356.

${ }^{44}$ In the the Styrian Diet the Slovenian minority could never realistically challenge the majority held by parties representing the German-speakers, though with specific measures some German-speaking localities could feel under threat. See for example the Cilli crisis of 1895 in J. Kwan, Judson, Schmid and Sutter.

${ }^{45}$ Richard Belcredi, 'Fragmente aus dem Nachlasse', Die Kultur, 7 (1906) 3: 275

${ }^{46}$ Somogyi mentions these meetings between the Autonomists and the Czechs. Somogyi, 'Pläne zur Neugestaltung der Habsburger Monarchie': 34. Kaiserfeld's colleague Rechbauer was extremely wary of upsetting the centralists. See Molisch, Briefe: 33-34. Péter Hanák has argued that the general German liberal attachment to centralism prevented them from playing a leading role in the monarchy. Péter Hanák, Ungarn in der Donau-monarchie. Probleme der bürgerlichen Umgestaltung eines Vielvölkerstaates (Vienna, 1984): 33-9. 
${ }^{47}$ See the report in the NFP, No. 698, 9 August 1866, MB.

${ }^{48}$ Ibid.

${ }^{49}$ Somogyi, Vom Zentralismus zum Dualismus: 252.

${ }^{50}$ Telegraf, No. 218, 11 September 1866, MB and Somogyi, 'Pläne zur Neugestaltung': 32.

${ }^{51}$ See the report Telegraf, No 222, 15 September 1866, AB and Somogyi, Vom Zentralismus: 64.

${ }^{52}$ Fremden-Blatt, 19, 20 and 21 September 1866 'Zur Neubildung der deutsch-österreichischen

Verfassungspartei’. See Oberösterreichisches Landesarchiv (OLA), Musealarchiv, Nachlaß Ignaz Figuly, carton 179.

${ }^{53}$ Telegraf, No. 225, 19 September 1866, MB.

${ }^{54}$ NFP, No. 731, 12 September 1866, MB.

${ }^{55} N F P$, No. 735, 16 September, MB.

${ }^{56}$ NFP, No. 722, 2 September 1866, MB. See also NFP, No. 725, 5 September 1866, MB.

${ }^{57}$ For background Richard Charmatz, Adolf Fischhof. Das Lebensbild eines österreichischen Politikers (Stuttgart and Berlin, 1910): 169-73.

${ }^{58}$ Adolph Fischhof, Ein Blick auf Österreichs Lage - Sendschreiben an die Redaction des 'Telegrafs' (Vienna, 1866): 6 and 26. The brochure made a significant impact in liberal circles. See for example the letter dated 16 October 1866 Anton Auersperg to Ludwig Frankl in Dr. Bruno von Frankl-Hochwart (ed.), Briefwechsel zwischen Anastasius Grün and Ludwig August Frankl (1845-1876) (Berlin, 1897): 233-35.

${ }^{59}$ Ibid: 31.

${ }^{60}$ Ibid: $37-8$.

${ }^{61}$ Ibid: 36 and 40.

${ }^{62}$ Ibid: $43-5$.

${ }^{63}$ Ibid: 41-2.

${ }^{64}$ Charmatz, Adolf Fischhof: 175.

${ }^{65}$ Ibid: 174. Anton Auerperg's nom-de-plume in Vormärz Austria was Anastasius Grün. He was a distant relative of the later Minister Presidents, Carl and Adolf Auerperg.

${ }^{66}$ NFP, No. 748, 29 September 1866, MB 'Ein Lösungsvorschlag'

${ }^{67}$ Telegraf, No. 227, 21 September 1866, AB. 
${ }^{68}$ See explanation in NFP, No. 760, 11 October 1866, MB.

${ }^{69}$ See the report in NFP, No. 754, 5 October 1866, AB.

${ }^{70}$ For example the centralists sent personal letters seeking support. Adolf Tschabuschnigg, a prominent Carinthian liberal and later Justice Minister in 1870, received letters around this time from Skene, Pratobevera and Schindler seeking his support. Kärntner Landesarchives, NachlaßAdolf Tschabuschnigg, carton 9.

${ }^{71}$ Somogyi, Vom Zentralismus: 69-70 and Somogyi, 'Pläne zur Neugestaltung': 41.

${ }^{72}$ Ibid.

${ }^{73}$ NFP, No. 760, 11 October 1866, AB.

${ }^{74}$ Somogyi, Vom Zentralismus: 68-9, NFP, No. 767, 18 October 1866, MB and NFP, No. 768, 19 October 1866, MB.

${ }^{75}$ Telegraf, No. 254, 23 October 1866, MB 'Die Wiener Abgeordneten Konferenz’. Interestingly this newspaper clipping is found in Kaiserfeld's personal papers. Steiermärkisches Landesarchiv, Nachlaß Kaiserfeld, carton 3.

${ }^{76}$ NFP, No. 756, 7 October 1866, MB and NFP, No. 798, 18 November 1866, MB.

${ }^{77}$ A copy of the draft can be found in the personal papers of the Upper Austrian liberal Ignaz Figuly. OLA, Nachlaß Figuly, carton 179, 'Programm Entwurf in Folge der Ausseer Besprechung'. Figuly echoed the sentiments of the Aussee Programme when addressing the Upper Austrian Diet. Vortrag des Dr. Figuly betreffend die Revision der Landes-Ordnung und der Landtags-Wahlordnung des Erzherzogthumes Österreich ob der Enns (Linz, 17 November 1866).

${ }^{78}$ NFP, No. 751, 2 October 1866, MB 'Zum Verfassungstreit'.

${ }^{79}$ Die Presse, No. 294, 27 October 1866 'Zur Klarstellung der Parteistandpunkte'. See also Johann N. Berger's reply defending the Aussee Conference, which he attended. NFP, No. 777, 28 October 1866, MB 'Auch ein Wort zur Klarstellung der Parteistandpunkte'.

${ }^{80} N F P$, No. 772, 23 October 1866, MB and NFP, No. 777, 28 October 1866, MB 'Hasner and Skene'.

${ }^{81}$ In private Herbst remained a centralist but in public would become one of the main supporters of the Compromise with Hungary. See Ignaz von Plener to Ernst von Plener 24 May 1867 in Molisch, Briefe: 39. ${ }^{82}$ Among the Austro-German liberals, Beust was seen as an outsider. Ernst Plener, Erinnerungen, 3 vols. (Stuttgart and Leipzig, 1911-21) 1: 98 and Pollak, Dreissig Jahre, 1: 173. 
${ }^{83}$ Redlich, Das österreichische Staats- und Reichsproblem, 2: 524-33.

${ }^{84}$ Stenographische Protokolle des niederösterreichischer Landtages, $5^{\text {th }}$ Session, 19 November - 30 November 1866, 26 November 1866: 19-61. The NFP had a copy of the draft in the morning edition of the first day of the debate. NFP, No. 806, 26 November 1866, MB ‘Adresse des niederösterreichischen Landtags’. On 14 November 1866 twelve liberal representatives met at Pratobevera's house in Vienna to decide on a common approach to the up-coming session of the Lower Austrian Diet. Some wanted information about the Aussee and centralist programmes but the real purpose was to talk about the upcoming Diet address to the Emperor NFP, No, 796, 16 November 1866, MB. See also the letter Pratobevera sent to the NFP. NFP, No. 797,17 November 1866, MB.

${ }^{85}$ Ibid, 20. The specific language used was of great importance. Friedrich Giehe wrote that 'the language itself is very decisive'. Friedrich Giehe, Zwei Jahre österreichischer Politik. Aus einem Tagebuch (Schaffhausen, 1868): 227. Entry dated 26 November 1866.

${ }^{86}$ Ibid, 42.

${ }^{87}$ Ibid, 55. The NFP signalled out Schindler's speech for praise in light of its German nature. NFP, No. 809,29 November 1866, MB.

${ }^{88}$ Ibid, 57.

${ }^{89}$ NFP, No. 810, 30 November 1866, MB.

${ }^{90}$ Zusammenstellung der Verhandlungen über die vom oberösterreichischen Landtage am 3. und 4. Dezember 1866 (Wels, [1866?]): 7-9. Drafts of the Upper Austrian address as well as the Moravia minority address were circulated to the press before the actual debates NFP, No. 810, 30 November 1866, AB

${ }^{91}$ Verhandlungen des Salzburger Landtages. $5^{\text {th }}$ session, 3 December 1866: 323-28.

${ }^{92}$ Landtags-Blatt über die Sitzungen des mit allerhöchsten Patente vom 14 October 1866 einberufenen mährischen Landtages, 4 December 1866: 114.

93 Ibid: $116-22$.

${ }^{94}$ For the address see ibid: $123-4$. For the NFP's observation that it was not overly centralist see NFP, No. 811, 1 December 1866, MB.

95 Ibid, 5 December 1866: 152-3.

${ }^{96}$ Ibid: 153 
${ }^{97}$ Ibid: $154-56$.

${ }^{98}$ Nine months later in August 1867 when the Compromise was long concluded and the delegations law in the process of passing in the Imperial Parliament, Skene continued to defend the idea of a central parliament and attacked the terms of the Compromise as ceding dominance to Hungary. This caused immense disquiet in liberal ranks and required speeches from Kaiserfeld and Herbst, among others, to quell the unrest and ensure continued liberal discipline in realizing the Compromise and creating a liberal constitutional, dualist system. See Die Neuegestzgebung Österreichs. Die Verfassungsgesetze und die Gesetze über die finanziellen Ausgleich mit Ungarn (Vienna, 1868): 573. Others shared Skene's opinions, see for example Der Ausgleich mit Ungarn vom österreichsichen Standpunkte beleuchtet (Vienna, 1867).

${ }^{99}$ Landtags-Blatt des mährischen Landtages: 174-179.

${ }^{100}$ These arguments mirrored his brother's defence of the 1865 suspension of the constitution. Richard Belcredi, 'Fragmente aus dem Nachlasse', Die Kultur 6 (1905) 4: 399-403 and Die Kultur 7 (1906) 4: 412-22. ${ }^{101}$ Landtags-Blatt des mährischen Landtages: 192-201.

${ }^{102}$ Rogge, Österreich, 2: 372.

${ }^{103}$ Die Verhandlungen des böhmischen Landtages über die Verfassungesfrage in der Zeit vom Dezember 1865 bis April 1867 (Prague, 1867): 50-53. See also the supplement in Rede des Abgeordneten Dr. Herbst gesprochen in der Sitzung des böhmischen Landtages am 7 Dezember 1866 (Prague, 1866): 17-18. ${ }^{104}$ Ibid: 54-57.

${ }^{105}$ Ibid: 57-61. Plener was a strong centralist and his despair at the Monarchy's state was expressed in more length in the brochure 'Der Zerfall Oesterreichs' published anonymously in March 1867. '[T]he collapse of Austria', wrote Plener ironically adopting František Palacký's famous phrase from 1848, 'is a European necessity'. [Ignaz von Plener], Der Zerfall Oestreich's von einem Deutschen Oestreicher (Leipzig, 1867): 70.

${ }^{106}$ Die Verhandlungen des böhmischen Landtages: 64.

${ }^{107}$ Ibid: 79.

${ }^{108}$ Rede des Herbst: 3-4.

${ }^{109}$ Ibid: 4.

${ }^{110}$ Ibid: 10.

${ }^{111}$ Ibid: 19. 
112 Ibid: $12-13$.

${ }^{113}$ Stenographische Protokolle über die Sitzungen des steiermärkischen Landtages. $5^{\text {th }}$ session von 19 November bis 22 Dezember 1866, 10 December 1866: 87-88. Also quoted in Krones, Moritz von Kaiserfeld, 260 who wrongly gives the date as 7 December 1866.

${ }^{114}$ Ibid.

${ }^{115}$ Ibid: 75.

116 The Carinthian Diet had the address debate on 14 December 1866. See Stenographische Protokolle der fünften Session des kärtnerischen Landtages zu Klagenfurt. 19 November bis 19 Dezember 1866, 14 December 1866: $145-65$.

${ }^{117}$ Redlich argues that during most of the negotiations both Deák and Andrássy opposed a dualist system with federalism in the Cisleithanian half. Redlich, Das österreichische Staats- und Reichsproblem, 2: 504 and 53335. During the August conferences in Vienna, Andrássy made clear that the Hungarians wanted a Germandominated, unified system in Cisleithania. Eisenmann, Le Compromis: 414, 420 and 431-32.

${ }^{118}$ NFP, No. 817, 7 December 1866, MB.

${ }^{119}$ Stenographische Berichte über die Sitzungen des galizienische Landtages im Jahre 1866, 7 December 1866: 126-130. See also $N F P$, No. 819,10 December 1866, AB.

${ }^{120}$ Rogge, Österreich, 2: 360. See also Józef Buszko, ‘The Polish Attitude towards the Compromise’ in Vantuch and Holotík, Der Österreichisch-Ungarische Ausgleich 1867: 600-606.

${ }^{121}$ Ibid, 133-35. See also NFP, No. 817, 7 December 1866, AB.

${ }^{122}$ Somogyi, Vom Zentralismus: 75.

${ }^{123}$ Gustav Kolmer, Parlament und Verfassung in Österreich. 5 vols. Vol. 1: 1848-1869 (Graz, 1972): 240. This stance was also made clear by the Czech leaders Rieger and Alois Trojan in the Bohemian Diet. NFP, No. 818, 8 December 1866, MB 'Die Landtage'.

${ }^{124}$ Politik, No. 350, 20 December 1905, 'Riegers Erinnerungen aus dem Jahre 1866’.

${ }^{125}$ Belcredi, 'Fragmente aus dem Nachlasse', Die Kultur 6 (1905) 4: 414.

${ }^{126}$ Rogge, Österreich, 2: 374

${ }^{127}$ Die Protokolle des österreichischen Ministerrates 1848-1867. 4/2, No. 119, 23 December 1866: 369-72. 
${ }^{128}$ Kolmer, Parlament und Verfassung in Österreich, 1: 245-7 and Redlich, Das österreichische Staats- und Reichsproblem, 2: 537-46.

129 Tages-Post, No. 9, 11 January 1867 'Zum Januar-Patent'. The Tages-Post was a Linz liberal newspaper. Eisenmann calculated that the extraordinary Parliament would result in 108 federalists and 95 centralists. Eisenmann, Le Compromis: 452. Charmatz used the same figure. Charmatz, Deutsch-österreichische Politik: 120.

${ }^{130}$ Giehe commented on their unity. Giehe, Zwei Jahre: 279 . The meeting is discussed in its essentials in Barbara Haider 'Introduction' in Barbara Haider (ed.), Die Protokolle des Verfassungsausschusses des Reichsrates vom Jahre 1867 (Vienna, 1997): 27-29. In a letter from Herbst to Pratobevera dated 9 January 1867 Herbst emphasises the need for unity. Molisch, Briefe: 35.

${ }^{131}$ See the report in NFP, No. 853, 14 January 1867, AB.

132 Ibid.

${ }^{133}$ NFP, No. 855, 16 January 1867, MB.

${ }^{134}$ Belcredi, 'Fragmente aus dem Nachlasse', Die Kultur 7 (1906) 3: 282.

${ }^{135}$ Ibid: 281. See also Giehe, Zwei Jahre: 287 and Eisenmann, Le Compromis: 454.

136 Ibid: 282.

${ }^{137}$ Ibid, 282. This linkage was made clear by Beust in his speech on 5 June 1867. See Beust, Aus Drei-Viertel Jahre, 2: 76. Herbst wanted more - perhaps even a parliamentary ministry, according to Beust. See Redlich, Das österreichische Staats- und Reichsproblem, 2: 659.

${ }^{138}$ Belcredi, 'Fragmente aus dem Nachlasse', Die Kultur, 7 (1906) 3, 274. Belcredi questioned whether the Austro-German liberals would really have seen through the blanket boycott.

139 The memorandums are quoted substantially in Redlich, Das österreichische Staats- und Reichsproblem, 2: 552. For background see also Somogyi, Vom Zentralismus, 89-92.

${ }^{140}$ Belcredi, 'Fragmente aus dem Nachlasse', Die Kultur 7 (1906) 3: 284-6. Beust often used the press in his political machinations. See Pollak, Dreissig Jahre, 1: 198-99.

${ }^{141}$ [Richard Belcredi], Über die Wahlen zum Landtage (Vienna, 1867).

${ }^{142}$ Kolmer, Parlament und Verfassung in Österreich, 1: 246-47. See also the comments in Alfred Arneth, Aus meinem Leben 2 vols. (Vienna, 1892), 1: 308 and Rogge, Österreich, 2: 385. 
${ }^{143}$ NFP, No. 865, 26 January 1867, MB.

${ }^{144}$ Belcredi, 'Fragmente aus dem Nachlasse', Die Kultur 7 (1906) 3: 286-88.

${ }^{145}$ Belcredi, 'Fragmente aus dem Nachlasse', Die Kultur 7 (1906) 2: 150.

${ }^{146}$ Full transcription can be found in Die Protokolle des österreichischen Ministerrates 1848-1867.4/2, No. 126, 2 February 1867: 398-406.

${ }^{147}$ Bernd Rottenbacher, Das Februarpatent in der Praxis. Wahlpolitik, Wahlkämpfe un Wahlentscheidungen in den böhmischen Ländern der Habsburgermonarchie 1861-1871 (Frankfurt, 2001): 87-123. In March 1867 with the re-elections to the Bohemian Diet and the realisation of the Compromise in train, Beust stated that ' $[\mathrm{t}] \mathrm{he}$ Emperor has spoken, the Emperor calls!'. See also Kolmer, Parlament und Verfassung in Österreich, 1: 251. ${ }^{148}$ Bartholomäus Carneri, Österreich nach der Schlacht bei Königgrätz. Ein freies Wort den Deutschen in Österreich gewidmet (Vienna, 1866):19.

${ }^{149}$ The effect of the political exclusion from Germany on the German-speaking population in the Habsburg Monarchy has often been mentioned but barely investigated in depth. Friedjung's interpretation that the real victims of 1866 were the Austro-Germans who thereby lost their political centre of gravity has been highly influential. Friedjung, Der Kampf um die Vorherrschaft: 515-516. Paul Molisch has a similar German nationalist viewpoint and argued that the separation of German nationalism from the Austrian state began from this time. Paul Molisch, Geschichte der deutschnationalen Bewegung in Österreich von ihre Anfängen bis zum Zerfall der Monarchie (Jena, 1926): 68-72. Recently Jörg Kirchhoff has noted the onset of a 'minority complex' resulting from 1866 and an increased stress on the German character of Austria. Jörg Kirchhoff, Die Deutschen in der österreichisch-ungarischen Monarchie. Ihr Verhältnis zum Staat, zur deutschen Nation und ihr kollektives Selbstverständnis (1866/67-1918) (Berlin, 2001): 40-44.

${ }^{150}$ See the suggestive comments in Judson, Exclusive Revolutionaries: 9-10.

${ }^{151}$ This was stated directly by the Finance Minister in the Taaffe government, the Galician-Polish leader Julian Dunajewski in the 1885 Budget debates. By making these comments, he attracted the deep enmity of the Austro-German liberals, especially their leader Ernst von Plener (the son of Ignaz von Plener). See Stenographische Protokolle über die Sitzungen des Hauses der Abgeordneten, 402 Sitting, 9 Session, 29 February 1885: 14002 and Plener, Erinnerungen, 2: 279 
${ }^{152}$ Lothar Höbelt (ed.), Der Vater der Verfassung. Aus den Denkwürdigkeiten Anton Ritters von Schmerling (Vienna, 1993): 121.

${ }^{153}$ Politik, No. 350, 20 December 1905, 'Riegers Erinnerungen aus dem Jahre 1866'.

${ }^{154}$ This policy is discussed in Oscar Jaszi, The Dissolution of the Habsburg Monarchy (Chicago, 1929): 103-4 and 115 and recently in Ágnes Déak, From Habsburg Neo-Absolutism to the Compromise 1849-1867 (Boulder, 2008): 41. See also Kolmer, Parlament und Verfassung in Österreich, 1:76. For a balanced assessment of Francis Joseph as monarch in his first years under the dualist system see Fritz Fellner, 'Kaiser Franz Joseph und das Parlament. Materialien zur Geschichte der Innenpolitik Österreichs in den Jahren 18671873, Mittheilungen des österreichischen Staatsarchivs 9 (1956): 287-347.

${ }^{155}$ Heinrich Friedjung, 'Der österreichisch-ungarische Ausgleich von 1867' in Heinrich Friedjung, Historische Aufsätze (Stuttgart and Berlin, 1919): 135-69 and Heinrich Srbik, 'Franz Joseph I. Charakter und Regeriungsgrundsätze' in Heinrich Srbik, Aus Österreichs Vergangenheit. Von Prinz Eugen zu Franz Joseph (Salzburg, 1949): 221-41.

${ }^{156}$ Robert Kann, 'The Austro-Hungarian Compromise of 1867 in Retrospect. Causes and Effects' in Vantuch and Holotík, Der Österreichisch-Ungarische Ausgleich 1867: 24-44. The article is also reproduced in Robert Kann, Dynasty, Politics and Culture: Selected Essays (Boulder, 1991): 194-218. 